\title{
Helicobacter Pylori Associated Autoimmune Diseases
}

\author{
Awad Ahmed Ahmed Hamedelnile \\ Sudan, Khartoum, Alemarat, Postal code 12217.
}

\begin{abstract}
Helicobacter pylori (H.pylori) can cause a wide array of gastric disorders such as chronic gastritis, peptic ulcer, and gastric cancer. In fact recent studies and accumulating evidence implicate helicobacter pylori in various extra intestinal autoimmune mediated diseases such as:chronic urticaria, psoriasis, schonleinhenoch purpura, behcet's disease, immune mediated thrombocytopenic purpura, food allergy, and multiple sclerosis, which will be discussed here. Various immunopathological theories was conceived in an effort to clarify this relationship between the helicobacter pylori and autoimmune diseases.However even these theories are not bases on solid experimental data. But helicobacter pylori eradication was shown to improve symptoms of these diseases and improving the quality of life.I wrote this research to arise some ambiguity in this topic and to be a constant draw attention to this topic.
\end{abstract}

Keywords:- H. pylori, Autoimmune Disease, Chronic Urticaria, Immunomodulation, $H$. pylori eradication.

\section{INTRODUCTION}

Sins helicobacter pylori was identified in 1983 it was believed to be a major cause of wide spectrum gastro intestinal diseases which will not be discussed her. More resent study and data collected from epidemiological and experimental recourses reveal a relationship between $\mathrm{H}$. pylori infection and several allergic and immunological disorders, Among different infectious agent implicated in different autoimmune disorder $\mathrm{H}$. pylori have got particular attention that because it was found to be induced the development of organ specific and non organ specific autoimmune diseases $(1)$. $\mathrm{H}$. pylori is a wide spared microbe that present in nearly $50 \%$ of the western world population and over $80 \%$ of those who live in developing countries are infected(2).

This organism has amazing ability to chronically persist in the host for many decades even if it was asymptomatic colonization This chronic persistence of the infection imperative a prolonged interaction between the bacteria and host immune system which makes it a possible autoimmune triggering agent. Autoimmune disorder was suggested being regulated by several environmental and genetic factors that play significant role in determining different clinical outcome.
The object of this review will focus the potential role of H.pylori infection in different autoimmune mediated diseases by a systemic approach, and also to draw attention of researchers to this inevitable relationship.

\section{POTENTIAL PATOPHYSIOLOGICAL MECHANISMOF INFECTION RELATED AUTOIMMUNITY}

Several virulence factors allowing this spiral shaped gram negative bacterium to chronically colonizing gastric mucosa. This virulence factors including: urease enzyme that allowing the bacteria overcome highly acidic environment in the stomach, also flagella are present in all infectious strains and important in colonizing the gut mucosa. The other important virulence factor associated with organism pathogenesis are cytotoxin-associated gen A (Cag A) and vaculating cytotoxin A(Vac a) toxin(3).

Several potential mechanism are suggested in effort to clarify the autoimmune disorder manifested in H.pylori infected patient. One of this mechanism are increase in gastric vascular permeability during atrophic gastritis caused by H.pylori that may increase the exposure to alimentary antigen. In addition to that chronic inflammatory process triggered by the microbe cause releases of inflammatory mediators and molecular mimicry to the circulation. Anti-gastric auto-antibody have been found in more frequently in patient with H.pylori infection (4).

Microbes can causes autoimmunity by inducing loss of self tolerance to self -antigen such as molecular mimicry in which common amino acids sequence are shared between the bacteria and host cells. His will affect causing generalized immune responseagainst both the host proteins and microbe antigen (5).Other suggested mechanism are polyclonal activation, epitope spread and by standard activation and superantigen phenomenon (6).

An interesting medical note was the observation of the effect of antibiotic therapy against the H.pylori which was found to reduces the clinical acuity of some autoimmune and allergic disorders. Studies on innate and acquired immune response to H.pylori found out that result of activation of toll like receptors by bacterial antigen are antiinflammatory mediator production, for example the effect of lipopolysacharid(LPS) of H.pylori on toll- like receptors was less potent than the activation of toll-like receptors by (LPS) of escherichia coli and result in poor 
proinflammatory response(7) . Similarly H.pylori flagellinevades recognition by toll-like receptors $(8)$.

In fact H.pylori vaculating cytotoxin (VacA) was found to affect CD4+helperlymphocytes by blocking its proliferation by interfering with T-cell receptor interleukin (IL-2) signalling pathway (9) .In addition preferential priming of naive T-cells into T-regulatory lymphocytes which are anti inflammatory regulator was influenced by H.pylori also H.pylori infection was found to cause anarching growth of $\mathrm{CD} 5+\mathrm{B}$ lymphocytes that produces poly and auto reactive $\operatorname{IgM}$ and $\mathrm{IgG} 3$ antibodes(10).

In fact autoantigen $\mathrm{H}+, \mathrm{K}+$ adenosine triphospate $(\mathrm{h}+/ \mathrm{K}+$.ATP ase $)$ was detected and activation of CD4+ Tlymphocytes were shown to cross react with $\mathrm{H}+, \mathrm{K}+-\mathrm{ATP}$ ase and H.pylori antigen as occur in autoimmune mediated gastritis (AIG) (11).

\section{$>$ H. pylori and Chronic urticaria}

Chronic urticaria (CU) are classified according to the aetiology to chronicspontaneous urticaria (CSU) and chronic inducible urticaria (CIU), CSU may be due to known(autoantibody) or unknown causes.

Pathogenetic mechanism of H.pylori inducing urticaria are poorly understood ,but several hypothesis are developed regarding this link between the organism infection and chronic urticaria. However immunomodulatory role of H.pylori in chronic urticaria is section of intense study as example:IgG and IgA antibodes to IgKDaH.Pylori associatedlipoprote in was found to be implicated in pathogenesis of chronic urticaria (12).

This auto- antibodes causing release of histamine when it react with $\mathrm{IgE}$ epitopes or with alpha chain of FceRI receptors(13) .Clinical assessment of this autoantibody is done autologeus serum skin test (ASST),if ASST is positive this indicate chronic urticarial exacerbation(14).

However the best evident of association of H.pylori with chronic urticaria is the improvement of the patient after $H$. pylori eradication .besides studiesrevels that H.pylori eradication in patient with antihistamine medication resistant chronic urticaria, will decreases the urticaria activity score and causes complete loss of urticaria symptoms (15).Resent experimental data suggest that H.pylori virulence genotype in the patient with chronic urticaria don't affect the clinical course of the disease(16) .

\section{$>$ H. pylori and Psoriasis}

Psoriasis is chronic autimmune mediated disease characterized by abnormal patches of the skin which are red, dray, Itch, and scaly (17).Resent studies suggest that h.pylori infection might act as triggering agent in psoriasis (18),(19). However this relationship are not based on solid experimental data.
But several causes were reported in which psoriatic lesion cleared up following successful eradication of H.pylori (20), (21) . And patient show less sever symptom compared to those with anti H.pylori antibodes serotype (22 ). An extensive study are need to rule out this suspicious co-existence of H.pylori infection and psoriasis disease.

\section{$>$ H. pylori and Vasculitides}

After considerable studies in the last years, taking about association of H.pylori infection and various vasculitides are becoming acceptable now.

\section{- Schoenlein-Henochpurpure}

Schonlein -henoch purpure (SHP)is disease characterized by inflammation involving small blood vessels of the skin, intestine, and joint, and the main symptoms is rash and burusing.SHP is the most common vasculitic disease in children but less common in adult (23) .Studies revels that after H.pylori eradication therapy symptoms of SHP were resolved(24), (25).

\section{- Behcet's Disease}

Behcet's disease (BD) is amulti system inflammatory disease of blood vessels that causes mouth sore, eye inflammation, skin rash, and genital ulcer, the exact causes remain enigmas but epidemiological studies suggests an autoimmine back ground (26), (27).A study on Turkish journals report the increase seropositivity of H.pylori cytotoxin-assosiated gen $-\mathrm{A}$ in patient with $\mathrm{BD}$ (28).Eradication of H.pylori is shown to reduces the clinical manifestation of the disease(29).

\section{- Immune Mediated Thrombocytopenicpurpura}

Immune thrombocytopenic purpure (ITP) is an idiopathic decries in the number of circulating platelets, manifested by bleeding tendency easy bruising and petechial hemorrhage.

Interestingly, anti CagA antibodes cross react with peptides present on platelets of ITP patient (30). This molecular mimicry here is not new as anti bodes against $\mathrm{H}+/ \mathrm{K}+$ _ATP ase were detected in autoimmune gastritis (12). Improvement of clinical symptoms and elevation in platelets count was reported in this patient afterH. pylori eradication (31),(32).

\section{Autoimmune Thyroid Diseases}

Although several studies support a role for H.pylori in autoimmune thyroid diseases this relation remain controversial. Cross reaction autoimmunity between the H.pylori and thyroid antigen has been proposed as a mechanism in H.pylori induced autoimmune thyroid diseases (AiTD)(33). 
Intact similar amino acids sequences are shard between the CagA of h.pylori and thyroid peroxidas were reported(34). Resent Study detect reduction in thyroid autoantibody after H.pylori eradication(35). Another research on Korean journal of internal medicine revel that prevalent of thyroid peroxidise antibody positive is more frequent in patient with H.pylori infection which may role out the association of H.pylori with AiTD (36).

De luis et al demonstrate that the titer of anti H.pylori immunoglobulins $\mathrm{G}(\mathrm{IgG})$ antibody in grave's disease and hashimoto thyroiditis patient was much higher compared with controls (37).

\section{$>$ Multiple Sclerosis}

H.pylori infection is considered as triggering agent of some neurological disorder such as multiple sclerosis, neuromylitis optica, Alzheimer's disease, Parkinson's, migraine, andserebrovascular diseases(38).

Multiple sclerosis is multifactorial neurodegenerative inflammatory disease of the central nervous system. Resent studies report the presents of immune modulatating feature of Sydney strain -1 antigen administrated in an experimental model of multiple sclerosis suggesting the potential role of H.pylori in the mechanism of these diseases(39).In contrast to that resent data reports negative correlation between h.pylori infection and multiple sclerosis particularly in western countries(40).

This conflicting findings may be due to ethnical and variation in the methods of analysis. However more studies are required to detect this boggling concomitantly coexistence of H.pylori and multiple sclerosis.

\section{$>$ H. pylori and Food Allergy}

Multiple mechanisms are suggested regarding the immunological response to food antigens. In genetic predisposed subject IgE are produced as a response to exposure to food antigens. Circulating IgE molecules binds high affinity receptors (FcERI) present on mast cells resulting in release of various mediators such as serotonin prostaglandins, leukotrienes and platelets activating factors (PAF)(41).

Experimental data suggest that $\mathrm{H}$. pylori can facilitate passage of antigen across the epithelium which cause immune response against it, Also, H.pylori was shown to be distorting the gastric barriers against food antigens which is formed by gastric mucosa that act as insulator against this antigen (42).

\section{CONCLUSION}

H. pylori are now considered to be one of the most important triggers of autoimmune disorders and the pathogenesis of this organism withe no doubt could explain this relation .further research is needed to rule out the possible role of H.pylori infection in autoimmune disorders.

\section{REFERENCES}

[1]. Ram M, Barzilai O, Shapira Y, Anaya JM, Tincani A, Stojanovich L, Bombardieri S, Bizzaro N, Kivity S, Agmon Levin N, Shoenfeld Y. Helicobacter pylori serology in autoimmune diseases - fact or fiction? Clin Chem Lab Med 2013; 51: 1075-1082 [PMID: 23079514 DOI: $10.1515 / \mathrm{cclm}-2012-0477]$

[2]. McColl KE. Clinical practice. Helicobacter pylori infection. N Engl J Med 2010; 362: 1597-1604 [PMID: 20427808 DOI: 10.1056/NEJMcp1001110]

[3]. Yula E, Nagiyev T, Kaya OA, Inci M, Celik MM, Köksal F. (2013). Detection of primary clarithromycin resistance of Helicobacter pylori and association between cagA (+) status and clinical outcome. Folia Microbiol; 58: 141-146.

[4]. Hernando-Harder AC, Booken N, Goerdt S, Singer MV, Harder H. (2009). Helicobacter pylori infection and dermatology diseases. Eur J Dermatol; 19: 431444.

[5]. Cooke A, Ferraccioli GF, Herrmann M, et al. (2008). Induction and protection of autoimmune rheumatic diseases. The role of infections Clin Exp Rheumatol.; 26 (1 Suppl 48):S1-7.

[6]. Amital H, Govoni M, Maya R, et al. (2008). Role of infectious agents in systemic rheumatic diseases. Clin Exp Rheumatol.; 26 (1 Suppl 48):S27-S32. [PubMed: 18570751]

[7]. Perez-Perez GI, Shepherd VL, Morrow JD, Blaser MJ. (1995). Activation of human THP-1 cells and rat bone marrow-derived macrophages by Helicobacter pylori lipopolysaccharide. Infect Immun.; 63:1183-1187. [PubMed: 7890370]

[8]. Gewirtz AT, Yu Y, Krishna US, et al. (2004). Helicobacter pylori flagellin evades toll-like receptor 5mediated innate immunity. J Infect Dis.; 189:19141920. [PubMed: 15122529]

[9]. Gebert B, Fischer W, Weiss E, et al. (2003). Helicobacter pylori vacuolating cytotoxin inhibits $\mathrm{T}$ lymphocyte activation. Science.; 301:1099-1102. [PubMed: 12934009]

[10]. Eli Magen, Jorge-Shmuel Delgado. (2014). Helicobacter pylori and skin autoimmune diseases. World J Gastroenterol; 20: 1510-1516.

[11]. Amedei A, Bergman MP, Appelmelk BJ, et al. (2003). Molecular mimicry between Helicobacter pylori antigens and $\mathrm{H}+, \mathrm{K}+$-adenosine triphosphatase in human gastric autoimmunity. J Exp Med.; 198:11471156. [PubMed: 14568977]

[12]. Bakos N, Fekete B, Prohászka Z, Füst G, Kalabay L.(2003). High prevalence of $\operatorname{IgG}$ and $\operatorname{IgA}$ antibodies to $19-\mathrm{kDa}$ Helicobacter pylori-associated lipoprotein in chronic urticaria. Allergy; 58: 663-667 [PMID: 12823128 DOI: 10.1034/ j.1398-9995.2003.00200.x]

[13]. Zuberbier T, Asero R, Bindslev-Jensen C, Walter Canonica G, Church MK, Giménez-Arnau AM,et al. (2009). EAACI/GA(2)LEN/EDF/WAO guideline: management of urticaria. Allergy; 64: 1427-1443 [PMID: 19772513 DOI: $10.1111 /$ j.13989995.2009.02178.x] 
[14]. Tong LJ, Balakrishnan G, Kochan JP, Kinét JP, Kaplan AP. (1997). Assessment of autoimmunity in patients with chronic urticaria. J Allergy Clin Immunol; 99: 461-465 [PMID: 9111489 DOI: 10.1016/S0091-6749(97)70071-X]

[15]. Magen E, Mishal J. (2012). Possible benefit from treatment of Helicobacter pylori in antihistamineresistant chronic urticaria. Clin Exp Dermatol 2013; 38: 7-12 [PMID: 23083221 DOI: 10.1111/j.13652230..04467.x]

[16]. Chiu YC, Tai WC, Chuah SK, Hsu PI, Wu DC, Wu KL, et al. (2013)The Clinical Correlations of Helicobacter pylori Virulence Factors and Chronic Spontaneous Urticaria. Gastroenterol Res Pract; 2013: 436727 [PMID: 23956739 DOI: $10.1155 / 2013 / 436727]$

[17]. National institute of arthritis and musculoskeletal and skin disease. October 2013 .qustion and answers about psoriasis .

[18]. Onsun N, Arda Ulusal H, Su O, Beycan I, Biyik Ozkaya D, Senocak M. (2012). Impact of Helicobacter pylori infection on severity of psoriasis and response to treatment. Eur J Dermatol; 22: 117120 [PMID: 22063790 DOI: 10.1684/ ejd.2011.1579]

[19]. Sáez-Rodríguez M, Noda-Cabrera A, GarcíaBustínduy M, Guimerá-Martín-Neda F, Dorta-Alom S, Escoda-García M, et al. (2002). Palmoplantar pustulosis associated with gastric Helicobacter pylori infection. Clin Exp Dermatol; 27: 720 [PMID: 12472559 DOI: 10.1046/ j.13652230.2002.01102_6.x]

[20]. Qayoom S, Ahmad QM. (2003). Psoriasis and Helicobacter pylori. Indian J Dermatol Venereol Leprol; 69: 133-134 [PMID: 17642857]

[21]. Martin Hübner A, Tenbaum SP. Complete remission of palmoplantar psoriasis through Helicobacter pylori eradication: a case report. Clin Exp Dermatol 2008; 33: 339-340 [PMID: 18201263 DOI: 10.1111/j.13652230.2007.02634.x]

[22]. Eli Magen, Jorge-Shmuel Delgado. Helicobacter pylori and skin autoimmune diseases. World J Gastroenterol 2014; 20: 1510-1516.

[23]. Blanco R, Martínez-Taboada VM, RodríguezValverde V, García-Fuentes M, González-Gay MA. Henoch-Schönlein purpura in adulthood and childhood: two different expressions of the same syndrome. Arthritis Rheum 1997; 40: 859-864 [PMID: 9153547 DOI: 10.1002/art.1780400513]

[24]. Machet L, Vaillant L, Machet MC, Büchler M, Lorette G. Schönlein-Henoch purpura associated with gastric Helicobacter pylori infection. Dermatology 1997; 194: 86 [PMID: 9031803 DOI: $10.1159 / 000246068]$

[25]. Shin JI, Koh H, Lee JS. Henoch-Schönlein purpura associated with helicobacter pylori infection: the pathogenic roles of $\operatorname{IgA}, \mathrm{C} 3$, and cryoglobulins? Pediatr Dermatol 2009; 26: 768-769 [PMID: 20199470 DOI: 10.1111/j.1525-1470.2009.01039.x]
[26]. Pay S, Simşek I, Erdem H, Dinç A. Immunopathogenesis of Behçet's disease with special emphasize on the possible role of antigen presenting cells. Rheumatol Int 2007; 27: 417-424 [PMID: 17171346 DOI: 10.1007/s00296-006-0281-6]

[27]. Kulaber A, Tugal-Tutkun I, Yentür SP, Akman-Demir G, Kaneko F, Gül A, et al. Pro-inflammatory cellular immune response in Behçet's disease. Rheumatol Int 2007; 27: 1113-1118 [PMID: 17549482 DOI: 10.1007/ s00296-007-0367-9]

[28]. Avci O, Ellidokuz E, Simşek I, Büyükgebiz B, Güneş AT. Helicobacter pylori and Behçet's disease. Dermatology 1999; 199: 140-143 [PMID: 10559580 DOI: $10.1159 / 000018221]$

[29]. Apan TZ, Gürsel R, Dolgun A. Increased seropositivity of Helicobacter pylori cytotoxinassociated gene-A in Behçet' $\mathrm{s}$ disease. Clin Rheumatol 2007; 26: 885-889 [PMID: 17021670 DOI: $10.1007 / \mathrm{s} 10067-006-0416-\mathrm{x}]$

[30]. Franceschi F, Christodoulides N, Kroll MH, Genta RM. Helicobacter pylori and idiopathic thrombocytopenic purpura. Ann Intern Med 2004; 140: 766-767 [PMID: 15126268].

[31]. Emilia G, Longo G, Luppi M, Gandini G, Morselli M, Ferrara L, Amarri S, Cagossi K, Torelli G. Helicobacter pylori eradication can induce platelet recovery in idiopathic thrombocytopenic purpura. Blood 2001; 97: 812-814 [PMID: 11157503]

[32]. Gasbarrini A, Franceschi F. Does H. Pylori infection play a role in idiopathic thrombocytopenic purpura and in other autoimmune diseases? Am J Gastroenterol 2005; 100: 1271-1273 [PMID: 15929756 DOI: 10.1111/j.1572-0241.2005.50224.x]

[33]. Ko GH, Park HB, Shin MK, Park CK, Lee JH, Youn HS, et al. Monoclonal antibodies against Helicobacter pylori cross-react with human tissue. Helicobacter 1997; 2: 210-215 [PMID: 9421126]

[34]. Tomb JF, White O, Kerlavage AR, Clayton RA, Sutton GG, Fleischmann RD, et al. The complete genome sequence of the gastric pathogen Helicobacter pylori. Nature 1997; 388: 539-547 [PMID: 9252185 DOI: $10.1038 / 41483$ ]

[35]. Bertalot G, Montresor G, Tampieri M, Spasiano A, Pedroni M, Milanesi B, et al. Decrease in thyroid autoantibodies after eradication of Helicobacter pylori infection. Clin Endocrinol (Oxf) 2004; 61: 650-652 [PMID: 15521972 DOI: 10.1111/j.13652265.2004.02137.X]

[36]. Choi,Y,M.,Kim,T.Y.,Kim,E.Y.,Jang,E.K., Jeon,M.J.,Kim,W.G.,...Kim,W.B.(2017).Association between thyroid autoimmunity and helicobacter pylori infection .the Korean Journal ,Medicin ,32(2),309313.doi :103904/Kjim.2014.369

[37]. de Luis DA, Varela C,de La Calle, et al .Helicobacter pylori infection is markedly increased in patient with autoimmune atrophic thyroiditis. J Clin Gasterointerol 1998;26:259-263. 
[38]. Mohebi N, Mamarabadi M, Moghaddasi M. Relation of helicobacter pylori infection and multiple sclerosis in Iranian patients. Neurol Int 2013; 5: 31-33 [PMID: 23888213 DOI: 10.4081/ni.2013.e10]

[39]. Boziki M, Grigoriadis N, Deretzi G, Lagoudaki R, Lourbopoulos A, Panayotopoulou E et al. Helicobacter pylori immunomodulative properties in a mouse model of multiple sclerosis. Immunogastroenterology. 2012; 1: 34-39.

[40]. Gang Yaoa, Ping Wangc, Xiang-Dan Luo, Ting-Min Yu, Robert A. Harris, Xing-Mei Zhang. Meta-analysis of association between Helicobacter pylori infection and multiple sclerosis. Neuroscience Letters. 2016; 620: 1-7.

[41]. Ma,

Z.F.,Majid,

$\mathrm{N}$.

A.,Yamaoka,T.,\&Lee,Y.Y.(2016).Food Allergy and Helicobacter pylori Infection: A Systamic review.Frontiers in microbiology, 7 . doi:10.3389/fmicb.2016.00368.

[42]. Matysiak-Budnik T, Terpend K, Alain S, et al. Helicobacter pylori alters exogenous antigen absorption and processing across a digestive epithelial cell line. Infect Immun 1998;66:5785-91. 